\title{
OOPEN ACCESS
}

International Journal of Management \& Entrepreneurship Research

P-ISSN: 2664-3588, E-ISSN:2664-3596

Volume 2, Issue 7, P.No. 463-475, December, 2020

Fair East Publishers

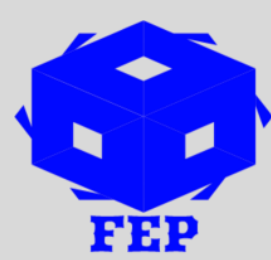

Journal Homepage: www.fepbl.com/index.php/ijmer

\section{IDENTIFYING BRAND EQUITY DIMENSIONS AND MEASURING ITS RELATIONSHIP WITH PRODUCT QUALITY DIMENSIONS: A STUDY ON JUICE BRANDS IN INDIA}

\author{
Dr. Saugat Ghosh ${ }^{1,}$ Mr. Karnak Roy ${ }^{2}$ \\ ${ }^{1}$ Asst. Professor (Marketing), Xavier Business School, St. Xavier's University Kolkata \\ ${ }^{2}$ Asst. Professor, Centre for Innovation and Technology, Administrative Staff College of India, \\ Hyderabad
}

Corresponding Author: Dr. Saugat Ghosh

Corresponding Author Email: saugat.ghosh@sxuk.edu.in

Article Received: 15-11-20

Accepted: 13-12-20

Published: $30-12-20$

Licensing Details: Author retains the right of this article. The article is distributed under the terms of the Creative Commons Attribution-NonCommercial $4.0 \quad$ License (http://www.creativecommons.org/licences/by-nc/4.0/) which permits non-commercial use, reproduction and distribution of the work without further permission provided the original work is attributed as specified on the Journal open access page.

\begin{abstract}
Brand Equity, which speaks about the perceived value of a product under a brand name, is one of the key measures of a brand's success. Higher level of brand equity could be translated as higher perceived value, growing market share and greater ROI. Thus, marketers are in eternal pursuit to device strategies for achieving higher brand equity. But for achieving this, knowledge about brand equity constructing components is necessary. Although theoretical studies have identified some brand equity constructing components, empirical validation of the theoretical constructs are vague. Studies in this field also states that product quality plays a significant role in creating brand equity, but empirically the interrelationship between product quality dimension and brand equity is not properly measured. The present study which is conducted on the juice brands in India aims to identify factors constructing brand equity of juice brands and also to estimate the impact of product quality dimensions of juice as a product on brand equity of the juice brands.
\end{abstract}

Keywords: Brand; Types of Brand Equity; Consumer Based Brand Equity; Dimensions of Brand Equity; Product Quality Dimensions

\section{INTRODUCTION}

The term, Brand Equity, speaks about the commercial value of a brand and this value is created by the perception of the consumers about the brand. Positive brand equity is a result of higher 
perceived value of a brand by its consumers and gets translated in greater market share and higher level of profitability. The reverse can also be observed if the brand equity is found to be negative. Although marketers are in eternal pursuit of creating and maintaining positive brand equity, not all of them are successful and the failure is largely due to the lack of knowledge about the constructing components of brand equity. Researchers in this field have identified the components which constitute brand equity, but most of the findings are limited to theoretical discussions and propositions. Besides that, no suitable methodology is so far discussed which can identify the important components that create brand equity and substantiate the theoretical claims, empirically. Aaker, (1996); Hanaysha et al. (2016) highlighted that among the identified components which create brand equity, consumer's perception about the quality of a product, plays the role of a major contributor. Brands operating in a product category has different perceptual position in the mind of the consumers, and this differentiation is largely due to the product quality offered by different brands. The impact of this perception goes up to the extent that, new product category, introduced under a particular mother brand name, also gets evaluated on the basis of the quality of some other product introduced under that brand name, in past, and was experienced by the consumers. Thus Herrmann et al., (2007), rightly pointed out that quality dimension of the product is highly important for a brand, in achieving higher perceptual position in the mind of the consumers and thereby achieving higher level of brand equity.

The present study is conducted on the juice brands and uses the perceptual data collected from 400 samples. Data were collected from the different malls of West Bengal, and from the collected response, two objectives are achieved: components which create brand equity is empirically identified and relationship between brand equity and product quality dimensions were empirically measured. The work also lays down a methodology which could be administered by the researchers and marketing practitioners for identification of the dimensions of brand equity and also for measuring its relationship with product quality dimension.

\section{REVIEW OF LITERATURE:}

The perspectives of illustrating and evaluating brand equity was subject to continuous changes and so do its definitions. Researchers who viewed brand equity from the financial perspective (followers of Firm Based Brand Equity perspective), defined it as present value of incremental cash flow generated by brand name of a product (Shocker and Weitz, 1988), or as an incremental cash flows which is accumulated by a brand over the unbranded version of the same offering (Simon and Sullivan 1993) or as financial value provided by a brand as a separable asset and used for accounting purpose and buying and selling activity of a brand (Feldwick, 1996). The term 'consumer-based brand equity' is coined by Keller (1993) and he defined brand equity as a differential effect of brand knowledge on the response of the consumer. Researchers who evaluated brand equity from this perspective defined it as added value conferred to a product and/or a service by a brand (Farquhar, 1989) or as an enhancement that a brand name confers to the perceived utility and desirability of a product (Lasser et al., 1995).

The benefits of brand equity are also illustrated in several research works. According to Aaker \& Jacobson (1994) Brands with higher level of brand equity were found to possess higher level of consumer preference, higher purchase intention and increased rate of loyalty. Impact of brand equity in modulating the consumer preference and purchase intention by exhibited by the study of Cobb Walgren et al. (1995). Impact of brand equity on long term cashflow and market share 
(Srivastava \& Shocker,1991) and on stock price (Simon \& Sullivan,1993) is also evident in the brand equity research works.

Brand equity research works could be broadly segregated into two broader segments namely direct and indirect approach. Researchers following the direct approach tried to measure the outcomes of brand equity. Ailawadi et al. (2003), tried to estimate the premium revenue earned by the brand due to higher level of brand equity while by measuring brand preference of the consumers, Park \& Srinivasan (1994) tried to measure brand equity. Kamakura \& Russell (1993) measured the consumer's perception about the utility provided by a brand while Green \& Srinivasan (1978), Rangaswamy et al. (1993) tried to measure consumer's perception about the overall brand value. Researchers following the indirect approach tried to conceptualize the formation of brand equity and its constructing components. Study of Cobb-Walgren et al (1995) identified four dimensions of brand equity while working upon the concept of Martin \& Brown (1991), Lassar et al. (1995) identified five dimensions of brand equity. Rajasekar \& Nalina (2008) also followed the research line of Lassar et al. (1995) and in their study conducted on the consumer durables brands in Indian market, they identified five dimensions of brand equity. The study of Yoo \& Donthu (2001) identified three brand equity dimensions consisting of ten items. Although the work is often cited as one best indirect approach research on consumerbased brand equity, some weakness related to the theoretical conceptualization of brand association and brand awareness and omitting brand personality from the model (Aaker, 1991) are also highlighted by several critics of the research.

The impact of product quality in creating the perception about the brand was always a topic of discussion and research works of Garvin (1984a, b 1988); Jacobson and Aaker (1987); Luchs (1986); Phillips et al. (1983); Shetty (1987) have demonstrated that high product quality is connected with greater margin of profit, higher market share and enhanced return on investment. The importance of product quality as a prime attribute to influence consumer's purchase decision is emphasized in the study of Shaharuddin et.al. (2011). Study of Hoisington and Naumann (2003) reemphasized the importance of product quality as his study revealed that product quality is one among the five major components that a consumer use while evaluating the performance of a company. Global brands, according to Hilman (2009), and Eze et al., (2012), use the supremacy of product quality as a weapon to enrich their brand equity in the foreign market. Product quality, as observed by Garvin (1984a); Shetty (1987); Takeuchi and Quelch (1983) is evaluated on the basis of the attributes of the products and Garvin (1984a) proposed eight product quality dimensions namely performance, features, reliability, conformance, durability, serviceability, aesthetics and service quality. Although performance and features, the first two quality dimensions of product, are closely related, according to Garvin, performance has association with the basic product characteristics and features are related with the secondary characteristics of the product. Reliability, as Garvin explained, deals with the performance of the product with respect to the expectation of consumers, the ability of product to meet the claimed or predefined specification or quality standards, comes under the conformance dimension. Durability, the fifth dimension of product quality, according to Garvin, deals with product's physical and/or economic lifespan and serviceability depends upon the ease of servicing of the product. Aesthetic dimension of the product quality is explained by the appeal associated with the product and this appeal may be generated by the taste, smell, feel and so on, of the product and finally the eighth dimension, which is termed as perceived quality, 
deals with the perception of the consumers about the image of the product, which is shaped by advertising, branding activities and previous experience of the consumers.

Garvin's work is often used by different researchers and marketing practitioners for evaluating the perception of the consumers about the quality of the product. Steven A. et al. (1992) used the dimensions to identify the product quality dimensions of industrial forest products (office furniture) and Shaharudin Jakpar et al. (2011) tested the impact of different product quality dimensions under price discount. The study of Yuhanis Mohamed Noor et al. (2019) tried to trace the influence of the product quality dimensions on the satisfaction level of the consumers of online apparels.

Subsequent to the review of relevant studies, some gaps are identified which are required to be addressed. The identified gaps are as follows:

\section{Research Gaps:}

RG1: Although much is discussed about the estimations of dimensions of brand equity, empirical studies in support of the theories are hardly available

RG2: Although much is said about the impact of product quality dimensions on brand equity, empirical evidence to support this theory is hard to find out.

\section{Research Objectives:}

RO1: To identify the dimensions of brand equity of the juice brands

RO2: To identify and estimate the relationship between brand equity and product quality dimensions

\section{Research Hypothesis:}

RH1: Significant dimensions of brand equity of the juice brands will be identified

RH2: Significant interrelationship could be observed between brand equity and product quality dimensions

\section{RESEARCH METHODOLOGY}

\section{Creating the pool of perceived brand quality attributes which motivates the selection of a} juice brand:

The first step was related to the identification of the qualities which consumers perceive as important before selecting a juice brand. A survey was conducted over 100 respondents, regular juice drinkers, where, by using a structured interview the respondents were asked to reveal their motivation behind the selection of a juice brand. The mentioned reasons were recorded for identification of unique set of qualities liable for the selection of the juice brands.

\section{Identification of Unique Brand Quality attributes which motivates the selection of Juice Brands:}

The gathered reasons, which were collected from consumers' response about their motivation behind selecting a particular juice brand, were scanned thoroughly for removal of repetition, as same reasons are repeated by many respondents. The removal of repetition was required 
identification of non-repetitive unique reasons responsible for selection of a juice brand. The gathered reasons were used in the next stage to collect consumer's perception about them.

Methodology to gather consumer's perception about the gathered and non-repetitive perceived brand quality attributes responsible for selecting a Juice Brand

The non-repetitive reasons responsible for selection of a particular juice brand were provided to the consumers of the juice brands to gather their perception. Perception data were collected by using a five-point Likert scale where 1 being not at all important and 5 being extremely important. The sample size in this stage was 400 and data were collected from different shopping malls of West Bengal, India. The collected data of this stage were used in the next stage to identify the dimensions of brand equity for the juice brands.

\section{Identification of the Dimensions of Brand Equity:}

A factor analysis was administered on the data collected about the consumer's perception of brand quality attributes responsible for selection of the juice brands. The findings of this stage were used in the next stage to create an index of Brand Equity.

\section{Methodology to estimate Brand Equity Index for Juice Brands:}

Findings of the factor analysis conducted on the consumer's perception of brand quality attributes responsible for selection of the juice brands was considered to construct the index of brand equity of juice brands. The factor analysis identified a set of significant factors of brand equity. Score of each factor is calculated by calculating the mean of the quality components under that respective factor. Finally, the index of brand equity has been calculated by taking the average of all factor scores. The process of calculating the index is elaborated bellow:

$$
\begin{gathered}
\text { IBE }=f\left(F_{i}\right) \text { where } i=1,2, \ldots, k \\
I B E=\sum\left({ }^{1} / n \sum F_{i}\right) \\
F_{i}=f\left(X_{i}\right) \text { where } i=1,2, \ldots ., j \\
F_{i}=\sum\left({ }^{1} / n \sum X_{i}\right)
\end{gathered}
$$

$\left[\mathrm{BEI}=\right.$ Index of Brand Equity, $\mathrm{F}_{\mathrm{i}}=$ Factors which constitute the brand equity, $\mathrm{X}_{\mathrm{i}}=$ quality components within a factor]

\section{Methodology to Create Indices of Product Quality Dimensions:}

The next step was related to the estimation of an index of product quality dimensions for the juice brands in study. In this context, product quality dimension, identified by Garvin, was used. Several researchers, like Steven A. et al. (1992); Shaharudin Jakpar et al. (2012); Yuhanis Mohamed Noor et al. (2019); and so on have used these dimensions for understanding the perception of consumers about quality of the product. Consumer's perception about the eight product quality dimensions were gathered by using a five-point Likert scale. Finally, index of each product quality dimensions was computed based on their average scores.

\section{Methodology to Measure the Interrelationship between Brand Equity and Product Quality Dimensions:}

Finally, to estimate the interrelationship between brand equity and product quality dimensions of a juice brands, a regression analysis is decided to be conducted where index of brand equity was considered as a dependent variable and indices of every product quality dimensions were considered as an independent variable. 


$$
\begin{gathered}
\mathrm{BE}=\mathrm{f}(\mathrm{PQD}) \\
\mathrm{IBE}=\alpha+\beta_{1} \text { Per }+\beta_{2} \text { Fet }+\beta_{3} \text { Rel }+\beta_{4} \text { Con }+\beta_{5} \text { Dur }+\beta_{6} \text { Ser }+\beta_{7} \text { Aes }+\beta_{8} \mathrm{PQ}
\end{gathered}
$$

$[\mathrm{IBE}=$ Index of Brand Equity, PQD = Product Quality Dimensions, Per $=$ Performance, Fet $=$ Feature, Rel $=$ Reliability, Con $=$ Conformance, Dur $=$ Durability, Ser $=$ Servicability, Aes $=$ Aesthetics, PQ = Perceived Quality]

\section{FINDINGS AND INTERPRETATIONS:}

Findings related to Unique Brand Quality Attributes which motivates the selection of Juice Brands:

As discussed in the earlier section, brand quality attributes, which motivates the selection of a particular juice brand were gathered and after removing the repetitions, 21 unique and nonrepetitive brand quality attributes are gathered. The list of the attributes is as follows (Table 1): Table 1

\begin{tabular}{|c|c|c|c|c|}
\hline $\begin{array}{l}\text { Brand provide what } \\
\text { I want }\end{array}$ & $\begin{array}{l}\text { Brand represents } \\
\text { my personality }\end{array}$ & $\begin{array}{l}\text { Changing brand is } \\
\text { difficult }\end{array}$ & $\begin{array}{l}\text { Brand is well } \\
\text { recognized among } \\
\text { other brands }\end{array}$ & $\begin{array}{l}\text { Brand provides } \\
\text { best price } \\
\text { among others }\end{array}$ \\
\hline $\begin{array}{l}\text { Brand provide } \\
\text { necessary changes I } \\
\text { want }\end{array}$ & $\begin{array}{l}\text { Brand provides } \\
\text { me satisfaction }\end{array}$ & $\begin{array}{l}\text { Brand provides } \\
\text { more than I } \\
\text { wished }\end{array}$ & $\begin{array}{l}\text { Brand is easy to } \\
\text { serve and consume }\end{array}$ & $\begin{array}{l}\text { My brand is } \\
\text { fresh in look and } \\
\text { taste }\end{array}$ \\
\hline $\begin{array}{l}\text { Brand is highly } \\
\text { prominent and } \\
\text { recognizable in } \\
\text { terms logo tagline } \\
\text { slogan etc. }\end{array}$ & $\begin{array}{l}\text { Advertisement } \\
\text { campaign is } \\
\text { attractive }\end{array}$ & $\begin{array}{l}\text { Brand is well } \\
\text { known }\end{array}$ & $\begin{array}{l}\text { Celebrities } \\
\text { associated with } \\
\text { brand are popular }\end{array}$ & $\begin{array}{l}\text { Brand is } \\
\text { synonymous } \\
\text { with product } \\
\text { category (Juice) }\end{array}$ \\
\hline $\begin{array}{l}\text { My brand motivates } \\
\text { me }\end{array}$ & & & & \\
\hline
\end{tabular}

List of Unique and Non-Repetitive Brand Quality Attributes Applicable to Juice Brand

\section{Findings related to Dimensions of Brand Equity}

As discussed earlier, a factor analysis was conducted on the perception data of consumers about the brand quality attributes responsible for selection of juice brands.

\begin{tabular}{|c|c|c|}
\hline \multicolumn{2}{|c|}{ Kaiser-Meyer-Olkin Measure of Sampling Adequacy. } & .784 \\
\hline \multirow{3}{*}{ Bartlett's Test of Sphericity } & Approx. Chi-Square & 1861.739 \\
\hline & $\mathrm{df}$ & 190 \\
\hline & Sig. & .000 \\
\hline
\end{tabular}

Table 2

The findings of Kaiser-Meyer-Olkin (KMO) method, which determine the factorability of the variable matrix show that the value is .784 which is greater than the 0.6 (Table 2). This states that the factorability of the matrix could be assumed. The $p$ value $(0.000)$ of Bartlett's test of sphericity is also found less than $\mathrm{p}<0.001$ and thereby stands significant (Table 2). 
The findings of the Communalities show the amount to which the extracted components are correlated with each other.

Table 3

\section{Communalities}

\begin{tabular}{lcc}
\hline & Initial & Extraction \\
\hline Brand_provides_the_best_among_others & 1.000 & .616 \\
Brand_is_wellknown & 1.000 & .579 \\
Brand_takes_care_of_my_requirement_in_detail & 1.000 & .501 \\
Brand_is_relaible & 1.000 & .729 \\
My_brand_is_fresh_in_look_and_taste & 1.000 & .492 \\
Advertisement_campaign_is_attractive & 1.000 & .616 \\
Consuming_my_brand_enhances_my_image & 1.000 & .512 \\
Brand_provides_me_satisfaction & 1.000 & .611 \\
Brand_provides_highest_level_of_purity & 1.000 & .481 \\
Brand_is_highly_prominant_and_recognizable_in_terms_logo_tagline_slogan_etc. & 1.000 \\
Changing_brand_is_difficult & 1.000 & .572 \\
Brand_provides_best_price_among_others & 1.000 & .660 \\
Celebrities_associated_with_brand_are_popular & 1.000 \\
Brand_is_synonymous_with_product_category (Juice) & 1.000 \\
Brand_is_easy_to_serve_and_consume & 1.000 \\
Brand_provide_what_i_want & 1.000 & .490 \\
Brand_provide_necessary_changes_i_want & 1.000 \\
Brand_represents_user_personality & 1.000 \\
Brand_provides_more_than_i_wished & 1.000 \\
Brand_is_well_recognized_among_other_brands & 1.000 & .711 \\
My_brand_motivates_me & 1.000 & .517 \\
\hline \multicolumn{1}{c}{ Extraction Method: Principal Component Analysis. } & .618 \\
\hline
\end{tabular}

Since all the values are greater than .4, none of the items are dropped from the model (Table 3 ). The total variance explained identifies the number of components who has an eigen values $\geq 1$ and this decides the number of components. According to Field (2005) the eigen values associated with each component explained the variance of the particular linear component, and here in this case (Table 4) the findings identified five components whose eigen value $\geq 1$ and that is 3.646, 3.298, 2.589, 1.301 and 1.109 (Table 4), while the other components have eigen value $<1$ and thus non-significant. The components also explained the variance of $18.026 \%$, $16.513 \%, 12.996 \%, 8.265 \%$ and $4.822 \%$ and together these five components explain $60.622 \%$ cumulative variance.

Table 4:

Total Variance Explained

\begin{tabular}{|c|c|c|c|c|c|c|c|c|}
\hline \multirow[t]{2}{*}{ Component } & \multicolumn{3}{|c|}{ Initial Eigenvalues } & \multicolumn{3}{|c|}{$\begin{array}{l}\text { Extraction Sums of Squared } \\
\text { Loadings }\end{array}$} & \multicolumn{2}{|c|}{$\begin{array}{l}\text { Rotation Sums of } \\
\text { Loadings }\end{array}$} \\
\hline & Total & $\begin{array}{l}\% \text { of } \\
\text { Variance }\end{array}$ & $\begin{array}{l}\text { Cumulative } \\
\%\end{array}$ & Total & $\begin{array}{l}\% \text { of } \\
\text { Variance }\end{array}$ & $\begin{array}{l}\text { Cumulative } \\
\%\end{array}$ & $\begin{array}{rl}\text { Total } \% & 0 \\
& \text { Variance }\end{array}$ & $\begin{array}{l}\text { f Cumulative } \\
\%\end{array}$ \\
\hline 1 & 3.646 & 18.026 & 18.026 & 3.646 & 18.026 & 18.026 & 3.59416 .718 & 16.718 \\
\hline 2 & 3.298 & 16.513 & 34.539 & 3.298 & 16.513 & 34.539 & 3.02814 .602 & 31.320 \\
\hline 3 & 2.589 & 12.996 & 47.535 & 2.589 & 12.996 & 47.535 & 2.41910 .317 & 41.637 \\
\hline 4 & 1.301 & 8.265 & 55.800 & 1.301 & 8.265 & 55.800 & 1.2318 & 50.536 \\
\hline
\end{tabular}




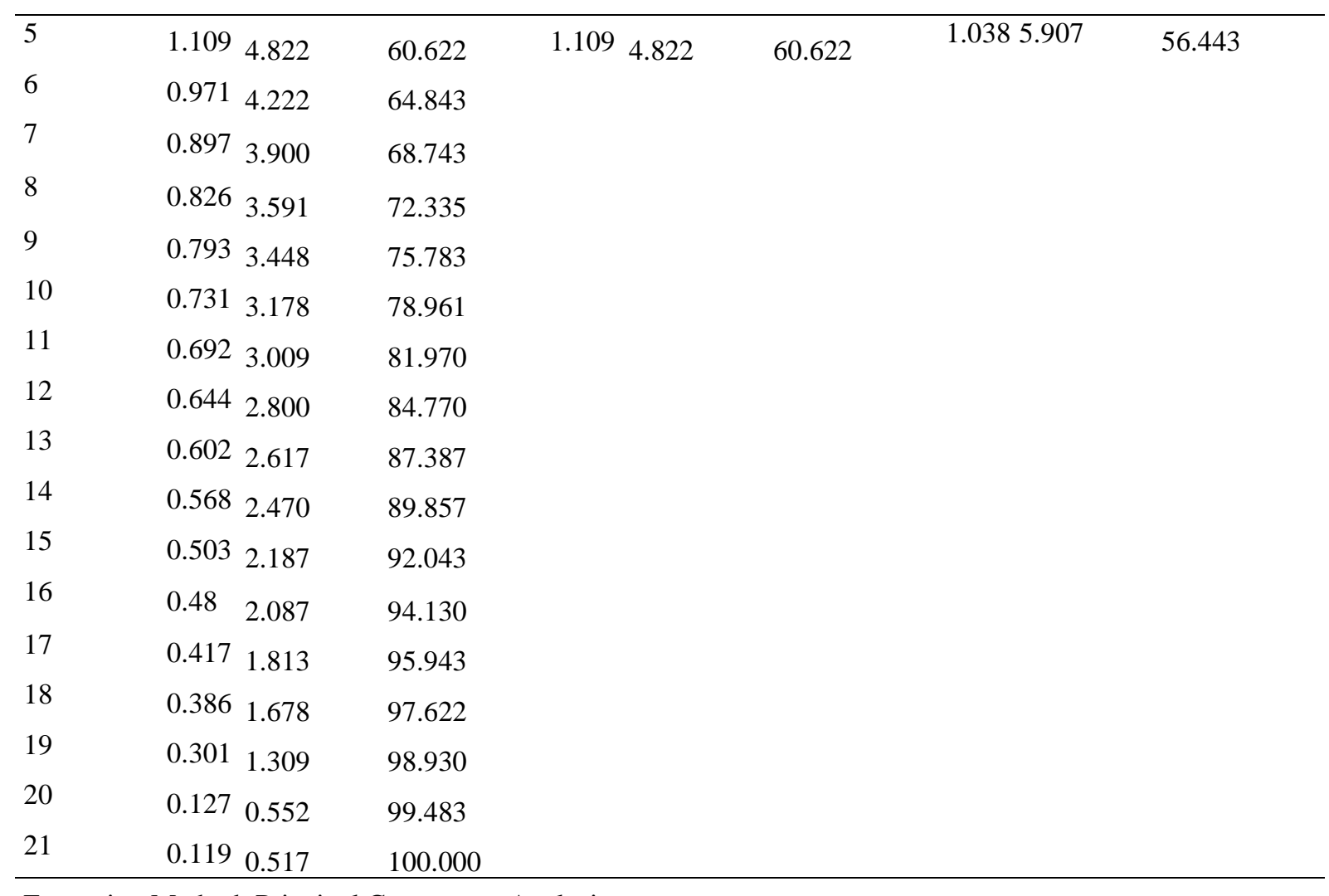

Extraction Method: Principal Component Analysis.

Findings of the Rotated Component Matrix

Using the Varimax orthogonal transformation, the resulted principal component was rotated orthogonally. 21 question items were reduced to five independent factors. The findings show that factor loadings from 0.779 to 0.594 were substantially loaded on component 1 , factor loadings from 0.768 to 0.436 were substantially loaded on component 2 , factor loadings from 0.716 to 0.498 were loaded on component 3 , factor loadings from 0.796 to 0.693 were loaded on component 4 , and 0.809 to 0.607 on component 5 (Table 5).

Table 5:

Rotated Component Matrix ${ }^{a}$

Component

Component Component Component Component Component

\begin{tabular}{lccccc} 
& & 2 & 3 & 4 \\
\hline Brand_provides_the_best_among_others & .103 & .512 & .716 & .218 & .128 \\
Brand_is_wellknown & .171 & .722 & .196 & .591 & .566 \\
Brand_takes_care_of_my_requirement_in_detail & .301 & .407 & .599 & .168 & .238 \\
Brand_is_relaible & .156 & .339 & .671 & .378 & .518 \\
My_brand_is_fresh_in_look_and_taste & .226 & .317 & .198 & .294 & .809 \\
Advertisement_campaign_is_attractive & .130 & .768 & .031 & .481 & .221 \\
Consuming_my_brand_enhances_my_image & .327 & .471 & .203 & .693 & .323 \\
Brand_provides_me_satisfaction & .594 & .179 & .398 & .476 & .099 \\
Brand_provides_highest_level_of_purity & .285 & .315 & .287 & .743 & 0.167 \\
Brand_is_highly_prominant_and_recognizable_in_te & .158 & .111 & .313 & .220 & .761 \\
rms_logo_tagline_slogan_etc. & .779 & .159 & .292 & .018 & .219 \\
Changing_brand_is_difficult & .257 & .497 & .098 & .698 & .230 \\
Brand_provides_best_price_among_others & &
\end{tabular}




\begin{tabular}{llllll} 
Celebrities_associated_with_brand_are_popular & .401 & .298 & .156 & .329 & .607 \\
$\begin{array}{l}\text { Brand_is_synonymous_with_product_category } \\
\text { (Juice) }\end{array}$ & .322 & .436 & .015 & .114 & .161 \\
Brand_is_easy_to_serve_and_consume & .406 & 0.419 & .715 & .323 & .017 \\
Brand_provide_what_i_want & .659 & .202 & .199 & .414 & .200 \\
Brand_provide_necessary_changes_i_want & .720 & .010 & .507 & .395 & .417 \\
Brand_represents_user_personality & 0.231 & .187 & .211 & .703 & .174 \\
Brand_provides_more_than_i_wished & .761 & .460 & .139 & .661 & .304 \\
Brand_is_well_recognized_among_other_brands & .167 & .473 & .237 & .796 & .351 \\
My_brand_motivates_me & .292 & .334 & .498 & .297 & .329 \\
\hline Extraction Method: Principal Component Analysis. & & & & \\
Rotation Method: Varimax with Kaiser Normalization. & & & & \\
a. Rotation converged in 6 iterations. & & & &
\end{tabular}

\section{Component 1 - Brand Loyalty}

The table of Rotated Component Matrix shows that the items highly loaded on component 1 indicates loyalty of the respondents towards their brand of juice. Thus, this factor is named as 'Brand Loyalty'. This factor has explained $18.026 \%$ of variance on all components with factor loading 0.779 to 0.594 (Table 5). The identified components play a significant role on the loyalty dimension associated and experienced by the respondents.

\section{Component 2 - Brand Awareness}

Items highly loaded on the second component manifest awareness of the respondent about their juice brands. The factor explains $16.513 \%$, of variability on all components with loadings of 0.768 to 0.436 (Table 5). It was named as "Brand Awareness'. The identified components play a significant role on the awareness dimension associated with the respondents.

\section{Component 3 - Perceived Quality}

The table of Rotated Component Matrix shows that the items highly loaded on component 3 indicates the impact of the perception of the consumers about the quality related issues of the juice brand. The component had $12.996 \%$, of variability on all components with loadings of 0.716 to 0.498 (Table 5). The factor is named as "Perceived Quality".

\section{Component 4 - Brand Association}

Component 4, which contains the highest number of variables (5 variables), embody the perception of consumers about brand association. The component had $8.265 \%$ of variability on all components with loadings of 0.796 to 0.693 (Table 5). This factor is formed by assembling the variables which significantly measures the perception of consumers related to the image, personality and recognition of the juice brands.

\section{Component 5 - Brand Asset}

The last factor, which is represented under Component 5, speaks about the distinctive qualities that consumers of a particular juice brand perceives that their brand possesses. Based on the variables within this component, the factor is termed as "Brand Assets". The component had $4.822 \%$ of variability on all components with loadings of 0.809 to 0.607 (Table 5).

Based on the components and their factor loading under the five identified factors, the factors are labelled as Brand Loyalty, Brand Awareness, Perceived Quality, Brand Association and Brand Asset. Thus, the findings of this research support the brand equity dimension theory of Aaker (1991). 
For identification and estimation of the interrelationship between brand equity and product quality dimensions of the juice brands, a regression analysis is required to be administered on the scores of brand equity and product quality dimensions of the juice brands. The score of brand equity score and that of product quality dimension score was estimated with respect to each consumer had been estimated in the following way:

Table 6

\section{Calculation of Brand Equity Score and Product Quality Dimension Score}

\begin{tabular}{ll}
\hline Brand Equity Score & $1 / 5$ (Brand Loyalty score + Brand Awareness Score + Perceived Quality Score + Brand \\
& Association Score + Brand Asset Score) \\
Product Quality & $\begin{array}{l}1 / 8 \text { (Performance + features + reliability + conformance + durability + serviceability + } \\
\text { Dimension Score }\end{array}$ \\
\hline
\end{tabular}

\section{Modelling Brand Equity as a function of Product Quality Dimensions:}

As discussed earlier, a regression analysis was conducted on the two indices, brand equity index and product quality dimension index, to find out the interrelationship among them. Index of brand equity was considered as dependent variable and index of product quality dimensions were considered as independent variables. The findings are as follows:

Table 7

Model Summary

\begin{tabular}{|c|c|c|c|c|}
\hline Model & $\mathrm{R}$ & R Square & Adjusted R Square & Std. Error of the Estimate \\
\hline 1 & $.833^{\mathrm{a}}$ & .693 & .607 & .2198133 \\
\hline
\end{tabular}

Table 8

\begin{tabular}{|c|c|c|c|c|c|c|}
\hline \multicolumn{2}{|c|}{ Model } & \multicolumn{2}{|c|}{ Unstandardized Coefficients } & $\begin{array}{l}\text { Standardized } \\
\text { Coefficients } \\
\text { Beta } \\
\end{array}$ & $\mathrm{t}$ & Sig. \\
\hline \multirow{10}{*}{1} & & & & & & \\
\hline & (Constant) & .371 & .103 & & 3.332 & .001 \\
\hline & Performance & .193 & .022 & .374 & 9.502 & .000 \\
\hline & Feature & .161 & .030 & .169 & 4.544 & .090 \\
\hline & Reliability & .197 & .037 & .051 & 1.360 & .002 \\
\hline & Conformance & .309 & .020 & .206 & 5.546 & .000 \\
\hline & Durability & .061 & .059 & .011 & 9.815 & .618 \\
\hline & Serviceability & .044 & .091 & .014 & 3.012 & .717 \\
\hline & Aesthetics & .102 & .271 & .403 & 3.020 & .021 \\
\hline & Perceived Quality & .222 & .058 & .167 & 1.879 & .008 \\
\hline
\end{tabular}

a. Dependent Variable: Brand Equity

The findings of the model primarily demonstrate that there is significant interrelationship between brand equity and product quality dimensions of the juice brands. The value of Adjusted $\mathrm{R}^{2}$ is 0.607 (Table 7) and this shows that almost $61 \%$ variability of the dependent variable, i.e. brand equity could be explained by the model. Five product quality dimensions, Conformance, Perceived Quality, Reliability, Performance and Aesthetic are found to have positive and significant relationship with brand equity of the juice brands with $5 \%$ level of significance. 'Conformance' is found to possess the highest positively significant relationship with Brand Equity of the juice brands. Keeping other variables constant, one-unit change in Conformance, 
changes the overall Brand Equity by .309 units (Table 8). Similarly, Perceived Quality is also found to have positively significant impact on Brand Equity and one-unit change in Perceived Quality is found to change the overall Brand Equity by .222 units (Table 8). Reliability, another product quality dimension, is found to have third highest positively significant impact on the brand equity of the juice brands and one-unit change in reliability changes the overall brand equity by .197 units (Table 8). Performance, is the fourth product quality dimension which has positively significant impact on brand equity and one-unit change in Performance, changes the overall brand equity by .193 unit (Table 8). Finally, Aesthetics is the last product quality dimension of the juice brands which is found to possess positively significant impact on the brand equity of juice brands and one-unit change in Aesthetic is found to change the overall brand equity by .102 units (Table 8). Feature, Durability and Serviceability are the three variables which are found to have no significant impact on Brand Equity (Table 8).

\section{CONCLUSION}

The purpose of the study has two facets, identification of the factors which constitute brand equity of the juice brands and finding and estimating the interrelationship between brand equity and product quality dimensions of juice brands. The study successfully identified the factors of brand equity of juice brands. It also found significant relationship between brand equity and product quality dimensions of the juice brands. Thus, it could be stated that methodology used in this study has been successful to achieve the research objectives. Similar studies could be conducted over the brands of other product categories to test the applicability of the methodology used in this study. Besides, it could also be observed that whether the theoretical construct of brand equity, provided by Aaker (1991) is applicable to brands of other product categories. Interrelationship between brand equity and product quality dimensions could also be tested for through similar studies.

\section{Reference}

Aaker, D.A. (1991). Managing Brand Equity: Capitalizing on the Value of a Brand Name. The Free Press, New York. NY.

Aaker,.D. A., \& Jacobson, R. (1994). The Financial Information Content of Perceived Quality. Journal of Marketing Research, 31 (May), 191-201.

Aaker, D. A. (1996). Measuring brand equity across products and markets. California Management Review, 38(3), 102-120.

Ailawadi, K. L., Lehmann, D. R., \& Neslin, S. A. (2003). Revenue premium as an outcome measure of brand equity. Journal of Marketing, 67 (October), 1-17.

Cobb-Walgren, C. J., Ruble, C. A., \& Donthu, N. (1995). Brand equity, brand preferences, and purchase intent. Journal of Advertising, 24(3), 25-40.

Eze, U. C., Tan, C. B., \& Yeo, A. L.Y. (2012). Purchasing Cosmetic Products: A Preliminary Perspective of Gen-Y. Contemporary Management Research, 8(1), 51- 60.

Farquhar, P.H. (1989). Managing Brand Equity. Marketing Research ,1(September), 24-33

Field, A. (2005). Discovering statistics using SPSS (2nd ed.). Sage Publications, Inc.

Feldwick, P. (1996). Do we really need 'Brand Equity? Journal of Brand Management, 4, 928.

Garvin, D. A. (1984a). Product quality: An important strategic weapon. Business Horizons 27(May/June), 40- 43. 
Garvin, D. A. (1984b). What does 'product quality' really mean? Sloan Management Review, 26(Fa11):25-43.

Garvin, D. A. (1988). Managing quality -The strategic and competitive edge. The Free Press, New York, NY

Green, P.E., \& V Srinivasan, (1978). Conjoint Analysis in Consumer Research: Issues and Outlook. Journal of Consumer Research, 5(2), 103-123

Hanaysha, J., \& Abdullah, H., \& Abdghani, Hasmini., N. (2016). Importance of product quality and service quality in developing brand equity. Journal for Global Business Advancement, 9(4), 390-401.

Herrmann, A., Huber, F., Shao, A., \& Bao, Y. (2007), Building Brand Equity via Product Quality. Total Quality Management and Business Excellence, 18(5), 531-544

Hilman, H. (2009). The relationship of Competitive Strategy, Strategic Flexibility and Sourcing Strategy on Organizational Performance (PhD Thesis), Uiniversiti Putra Malaysia, Malaysia.

Hoisington, S., \& Naumann, E. (2003). The loyalty elephant. Quality Progress, 33-41.

Jacobson R, O., \& Aaker. D.A. (1987). The strategic role of product quality. Journal of Marketing, 5(October), 144

Kamakura, W. A., \& Gary, J.R. (1993). Measuring Brand Value with Scanner Data. International Journal of Research in Marketing, 10, 9-22.

Keller, K. L. (1993). Conceptualizing, Measuring, and Managing Customer-Based Brand Equity. Journal of Marketing, 57(1), 1-22

Lassar, W., Mittal B., \& Sharma A. (1995). Measuring Customer-Based Brand Equity. Journal of Consumer Marketing, 12(4): 11-19

Luchs, R. (1986). Successful businesses compete on quality-not costs. Long Range Planning 19(February), 12-17

Martin, G., S., \& Brown, T. J. (1991). In Search of Brand Equity: The Conceptualization and Operationalization of the Brand Impression Construct. Winter Educator's Conference Proceedings, 1991, Terry L. Childers et al. eds. Chicago: American Marketing Association, 431-438.

Park, C.S., \& Srinivasan, V. (1994). A Survey-Based Method for Measuring and Understanding Brand Equity and Its Extendibility. Journal of Marketing Research, 31(5), 271-288

Phillips, L. W., Change, D.R., \& Buzzell, R.D. (1983). Product quality, cost position, and business performance: A test of some key hypotheses. Journal of Marketing 49(Spring):26-43.

Rajasekar, N., \& Nalina, K. G. (2008). Measuring customer-based brand equity in durable goods industry. Journal of Marketing and Communication, 4(1), 48-58.

Rangaswamy, A., Burke, R., Oliva, T. (1993). Brand Equity and the Extendibility of Brand Names. International Journal of Research in Marketing, 10 (March): 61-75.

Shaharudin, M.R., Hassan, A.A., Salleh, M.M., Ali, S.M., Harun, E.H., Jalil, M.A. \& Abdul, N.A. (2011). The relationship between extrinsic and intrinsic attributes of product quality with brand loyalty on Malaysia national brand Motorcycle/Scooter, MODENAS. Interdisciplinary Journal of Contemporary Research in Business, 2(9), 135-149.

Shetty, Y. K. (1987). Product quality and competitive strategy. Business Horizons 30(May/June):46-52. 
Shocker, A.D., \& Barton, W. (1988). A Perspective on Brand Equity Principles and Issues. In Defining, Measuring, and Managing Brand Equity. Report No. 88-104. Ed. Lance Leuthesser. Cambridge, MA: Marketing Science Institute, 2-4.

Simon, C. J., \& Sullivan, M. W. (1993). The measurement and determinants of brand equity a financial approach. Marketing Science, 12(1), 28-52.

Sinclair S. A., Hansen B.G., Fern E.F. (1993), Industrial Forest Product Quality: An Empirical Test of Gravin's Eight Quality Dimensions. Wood and Fiber Science. 25(1), 66-76

Srivastava, R., \& Shocker, A. D. (1991). Brand equity: A perspective on its meaning and measurement. Marketing Science Institute Working Paper Series, Report 91-124, Marketing Science Institute, Cambridge, MA.

Takeuchi, H., \& Quelch, J. A. (1983). Quality is more than making a good product. Harvard Business Review, 83(July/August), 139-145

Yoo, B., Donthu N. (2001) Developing and validating a multidimensional consumer-based brand equity scale. Journal of Business Research, 52(1). 